SHORT REPORT

\title{
Sledging in childhood: just harmless fun?
}

\author{
J G Cooper, J S Thomson, A J Cooper
}

Emerg Med J 2003;20:538-539

S ledging is one of the most enjoyed winter pastimes. In Britain the arrival of snow is usually heralded by an exodus of children to the local parks and hills. However, sledging can result in serious injury and attendance to the accident and emergency (A\&E) department. Sledging accidents frequently involve children and can be fatal. ${ }^{1}$ The aim of this study was to establish the number of sledging related injuries presenting to our paediatric A\&E department and to study the cause and patterns of these injuries to see if any preventative measures may reduce the number of accidents.

\section{METHODS}

The first snow of the winter in our area lay on the ground from the 22 December 2001 to the 6 January 2002. During this period the attendances to our paediatric A\&E department were identified from computer records. The A\&E cards and hospital notes were then examined retrospectively to determine those injuries that occurred as a result of sledging accidents. These cases were then studied in greater detail to establish the mechanism and extent of injury in each instance and to try to ascertain what safety measures could be recommended to try to reduce morbidity.

\section{RESULTS}

During the 16 day study there were a total of 422 attendances at the paediatric A\&E department. Of these 46 patients $(10.9 \%)$ were identified as having suffered injuries as a result of sledging. There were 25 boys and 21 girls. The ages ranged from 2-13 years (mean 8.6 years) and the mechanisms of injury were very diverse (table 1 ).

In total there were 49 injuries because three patients had two injuries. Many of these were significant and there were 16 fractured bones (table 2).

Of the 46 patients as a whole, $8(17 \%)$ required admission to hospital from A\&E, a further $12(26 \%)$ were followed up in outpatient clinics, and the remaining 26 (57\%) were discharged home from the A\&E department after initial consultation and treatment. There were no fatal injuries in our series of patients.

Table 1 Mechanism of sledging injury

\begin{tabular}{ll}
\hline Mechanism of injury & $\begin{array}{l}\text { Number of } \\
\text { patients }(\%)\end{array}$ \\
\hline $\begin{array}{l}\text { Falling off sledge } \\
\text { Colliding with stationary objects, for example, trees, }\end{array}$ & $12(30)$ \\
fences, bollards & \\
Colliding with other sledges, passengers and pedestrians & $5(11)$ \\
Twisting foot or ankle underneath sledge & $4(9)$ \\
Putting limbs out to stop sledge & $2(4)$ \\
Catching hand in edge of sledge & $2(4)$ \\
Falling when pulling/running after sledge & $2(4)$ \\
Not recorded & $5(11)$ \\
\hline
\end{tabular}

\section{DISCUSSION}

The recreational morbidity from sledging has been previously discussed in the British medical literature though not for the past 10 years. $^{23}$ Safety measures such as increased parental supervision, clearing and cordoning off popular slopes, and the wearing of protective clothing then recommended would seem to have not been implemented. This study found that at a traditionally a more "medical" time of year participation in sledging provided a sizeable source of trauma. From our records it was not possible to establish whether this meant there was an overall increase in the normal trauma workload at this time of year though it does suggest that there is still cause for concern at the number and severity of injuries attributable to sledging.

Sledges travel fast, are difficult to steer and hard to brake. They are often driven by young novices on slopes that are crowded, unprepared, and unsupervised. Despite the free availability of sledges and the uncontrolled access to what can be a very high speed activity there seems to be little awareness that sledging is a potentially dangerous activity and few safety precautions are taken.

Collisions with stationary objects are clearly preventable and would have reduced the number of accidents in this series by $26 \%$ ( 12 of 46 ). Furthermore, children often sledge on crowded slopes without parental supervision in traffic that is, in the authors own experience, largely chaotic and uncontrolled. In this study the avoidance of collisions with

Table 2 Details of sledging injuries

\begin{tabular}{ll}
\hline Site of injury & Number \\
\hline Head/face $(\mathbf{n}=11)$ & \\
Head injury & 4 \\
$\quad$-admission & 3 \\
Facial injury & 7 \\
$\quad$-bruising & 2 \\
- laceration & 4 \\
$\quad$-dental & 1 \\
Lower limb ( $\mathbf{n}=\mathbf{2 0})$ & \\
Soft tissue & 9 \\
Laceration & 2 \\
Fracture & 9 \\
\# femur & 1 \\
\# tib/fib & 2 \\
\# tibia & 2 \\
\# ankle & 2 \\
\# 1st metatarsal & 1 \\
\# 5th metatarsal & 1 \\
Upper limb ( $\mathbf{n}=13)$ & \\
Soft tissue & 5 \\
Laceration & 1 \\
Fracture & 7 \\
\# clavicle & 1 \\
\# humerus & \# radius/ulna \\
\# radius & \# scaphoid \\
Thoracolumbar ( $\mathbf{n}=5)$ & 1 \\
Soft tissue & 1 \\
\hline
\end{tabular}


other sledges would reduce the number of accidents by $11 \%$ ( 5 of 46). The use of sledging slopes that have sufficient run off area, are free from obstructions such as trees, boulders, and fences and have properly cordoned off runs has been suggested before and may reduce injuries by up to $56 \%{ }^{2}$

There were blows to the face and head in $24 \%$ ( 11 of 46 ) cases. There were no cases of skull or facial bone fracture but three of the four isolated head injuries were severe enough to merit admission for observation. There was no documentation of protective headgear having been worn in any instance. The wearing of bicycle safety helmets has reduced the number of head injuries ${ }^{4}$ leading to consideration of legislation to enforce their mandatory use. ${ }^{5}$ There is as yet no evidence to support a benefit of using protective headgear when sledging but this would seem to be common sense.

The upper limb was injured in $28 \%$ (13 of 46) and the lower limb in $43 \%$ (20 of 46 ) of cases and there were 11 long bone injuries. Many of these children were in the rapid phase of adolescent growth when long bone fractures may have severe effects on growth and development.

Falling off a sledge was a common mechanism of injury $(30 \%)$ and though the position of the patient at the time of injury was not recorded in all cases at least two patients were standing up "sledge surfing". Innovative sledging positions, such as travelling prone and head first have been discouraged previously. ${ }^{1}$ The practice of towing sledges behind cars has had disastrous consequences resulting in death ${ }^{1}$ and severe injury. ${ }^{3}$

In almost all cases the children were using familiar plastic sledges though one was using a skateboard. Catching hands on the sharp edges of these vehicles resulted in two injuries and may have been prevented by the use of protective gloves. Furthermore, it is common to damage feet and ankles by catching them under the sledge $(10 \%)$. It would be expected that this would occur especially when braking but it was not possible to derive this accurately from the notes. A further $5 \%$ of injuries resulted from bringing the sledge to a standstill. The use of strong footwear and slopes with substantial run off areas may be able to reduce the number of these injuries.

In conclusion the following recommendations are made:

- Protective clothing, particularly headgear and gloves should be worn.

- There should be adult supervision of children on sledges at all times.

- Sledging slopes should be free from immovable obstructions such as trees, posts, and bollards and have sufficient run off area to allow the sledge to come to a halt without rapid braking.

- Consideration should be given to cordoning off popular runs so as to permit the safe ascent of children at the side of the run without risk of collision with oncoming traffic.

- The practice of "snow surfing" should be discouraged, as should sledging in the prone position.

- Sledging should only be under taken in vehicle designed for the purpose and not on skateboards, plastic bags, or trays, etc.

- Instructions detailing the dangers of sledging, the appropriate protective clothing required, and the environment in which to safely use them should be available with the sale of all sledges. This information could also be distributed to children and parents through school teachers and medical staff or via the distribution of leaflets or other advertisements.

With the introduction of a few simple and common sense safety requirements hopefully this winter pastime may become a lot safer without detracting from the obvious enjoyment it gives to children.

\section{Contributors}

Jamie G Cooper, study concept, study design, principal author, data collection and analysis, guarantor of study. John S Thomson, data collection and analysis. Angus J Cooper, manuscript editing.

\section{Authors' affiliations \\ J G Cooper, J S Thomson, A J Cooper, Department of Accident and Emergency, Aberdeen Royal Infirmary, Aberdeen, UK}

Correspondence to: Mr J G Cooper, Department of Accident and Emergency, Aberdeen Royal Infirmary, Aberdeen AB25 2ZN, UK; jaime.julie@totalise.co.uk

Accepted for publication 16 September 2002

\section{REFERENCES}

1 Kim PC, Haddock G, Bohn D, et al. Tobogganing injuries in children. J Pediatr Surg 1995;30:1135-7.

2 Sloan JP, Maheson M, Dove AF. How dangerous is sledging? BMJ 1985;290:821.

3 Cohen B, Shewring D, Chapman P. Sledging injuries. BMJ 1991;302:596

4 Thompson RS, Rivara FP, Thompson DC. A case-control study of the effectiveness of bicycle safety helmets. N Engl J Med 1989;320:1361-7.

5 Spence L, Dykes EH, Bohn DJ, et al. Fatal bicycle accidents in children: a plea for prevention. J Pediatr Surg 1993;28:214-16. 